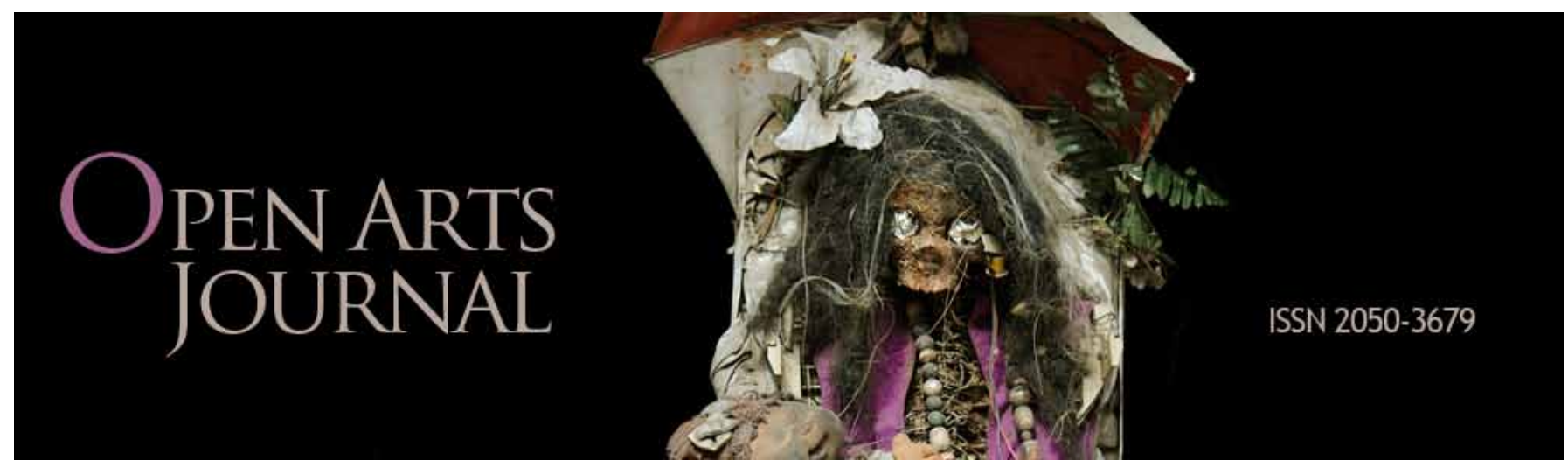

\title{
AT THE BOTTOM OF THE GARDEN: THE CAFFEAUS OF VILLA ALBANI Jane Lomholt
}

This essay addresses the history and design of a pavilion at the Villa Albani in Rome. Built in 1764 by the architect Carlo Marchionni, possibly to a design by the client, the antiquarian Cardinal Alessandro Albani, this is a caffeaus (or coffee house, to offer a rough translation) featuring an eleven-bay semi-circular portico of Doric order. The taking of coffee after dinner had become a popular pastime and some, who could afford it, built special pavilions in their gardens for this purpose. Pope Benedict XIV, for instance, had a caffeaus built in his garden at the Quirinal Palace some twenty years earlier where he could withdraw from the formalities of courtly life. For Cardinal Albani, the caffeaus also served as an extension to his Casino, where his vast collection of sculptures, busts and basins was displayed. With the aid of his librarian, the German scholar and writer Johann Joachim Winckelmann, Albani displayed his immense and unique collection of art and antiquities in a way that served to underline his own scholarship, wealth and position of affinity with Rome. The Villa and its splendours were not to be missed by the Grand Tourists. The essay situates this exceptional pavilion in the wider context of his Villa, whose gardens and buildings today lie in various stages of disrepair and are closed to the public, except by private invitation.

Keywords: pavilion, Villa Albani, Caffeaus, Carlo Marchionni, Winckelmann, art collection.

\begin{abstract}
Jane Lomholt
Jane Lomholt studied architecture in Aarhus, Denmark, and Portsmouth, England. She obtained her PhD from the University of Sheffield, and recently retired from Lincoln School of Architecture, where she was Head of Humanities. With Soumyen Bandyopadhyay, Renée Tobe and Nicholas Temple, she co-edited The Humanities in Architecture Design:A Contemporary and Historical Perspective (Routledge, 20I0), and with Paul Emmons and John Hendrix, The Cultural Role of Architecture, Contemporary and Historical Perspectives (Routledge, 2012), to which she contributed the essay 'Villa Albani: Repository of Multiple Narratives.'
\end{abstract}

\section{At the Bottom of the Garden:The Caffeaus of Villa Albani \\ Jane Lomholt \\ DOI: http://dx.doi.org/ I0.5456/issn.2050-3679/20 I3w03jl}

To view the images used in this article in a larger and more detailed format, follow this link:

http://openartsjournal.org/issue-2/issue-2-galleries/article-2 


\section{AT THE BOTTOM OFTHE GARDEN: THE CAFFEAUS OF VILLA ALBANI}

\section{Jane Lomholt}

\section{Abstract}

This essay addresses the history and design of a pavilion at the Villa Albani in Rome. Built in 1764 by the architect Carlo Marchionni, possibly to a design by the client, the antiquarian Cardinal Alessandro Albani, this is a caffeaus (or coffee house, to offer a rough translation) featuring an eleven-bay semi-circular portico of Doric order.The taking of coffee after dinner had become a popular pastime and some, who could afford it, built special pavilions in their gardens for this purpose. Pope Benedict XIV, for instance, had a caffeaus built in his garden at the Quirinal Palace some twenty years earlier where he could withdraw from the formalities of courtly life. For Cardinal Albani, the caffeaus also served as an extension to his Casino, where his vast collection of sculptures, busts and basins was displayed. With the aid of his librarian, the German scholar and writer Johann Joachim Winckelmann, Albani displayed his immense and unique collection of art and antiquities in a way that served to underline his own scholarship, wealth and position of affinity with Rome. The Villa and its splendours were not to be missed by the Grand Tourists. This essay situates this exceptional pavilion in the wider context of his Villa, whose gardens and buildings today lie in various stages of disrepair and are closed to the public, except by private invitation.

To the north of Rome, just outside the Aurelian walls on via Salaria, lies what is considered to be the last Roman villa suburbana. It is not an ancient villa, as one might expect; it is recent, built in the mid-1700s by cardinal Alessandro Albani (1692-1779), the eminent scholar and collector of antiquities, and nephew of Pope Clement XI. Its location on the old salt road was well chosen, within easy reach of his palazzo inside the city on via Quattro Fontane and only fifteen miles from Tivoli, where both Villa d'Este and Villa Adriana were rich sources of antiquarian artefacts at the time, and indeed, were excavated by Albani himself (Leppmann, 1970, p.204).' It was ideal for the middle-aged man's villeggiatura.The countryside was beautiful, the rolling hills covered with olive groves and vineyards interrupted occasionally by picturesque clusters of scattered hamlets. From its very beginnings, the villa

I Both Villa d'Este and Villa Adriana were owned by Cardinal Albani's distant relative by marriage, the Duke of Modena.
- grounds, gardens, buildings - were studded with the finest and largest collection of statues, masks, basins and bas-reliefs that became the highpoint of every young man's (and some women's) visit to Rome on his Grand Tour.Visiting the cardinal at his villa in 1770, Charles Burney, the English musical historian noted that the villa was located in a place of great beauty; he wrote that it was 'new and fitted up with infinite taste - it is full of the most precious remains of antiquity, adding that the house was cleaner than any he had seen in Italy.

Burney gives the pavilion special attention: 'the semicircle or coffeehouse [is] elegant and full of fine statues and bas-reliefs, among them some Etruscan with musical instruments described by Wynkleman [sic]' (p. |48). A century later Henry James praised the villa for retaining much of its original charm. The surrounding countryside did not go unnoticed by James either, when he wrote: 'The light today is magnificent; the Alban Hills of an intenser [sic] broken purple than I had yet seen them - their white towns blooming upon it like vague projected lights' (pp.228-9). Not until the turn of the nineteenth century did industry and development encroach upon this idyll. Today the surrounding neighbourhood has grown so dense that it is hard to envisage the distant hills behind the apartment blocks and office buildings without the prompts offered by old etchings and paintings. Asleep and all but forgotten, the villa (including its pavilion and gardens) lies in semi-dereliction with no apparent plans for upkeep or a future restoration.

Inspired by a recent visit, this essay explores the Villa Albani as the architectural realisation of a conceptual project developed by cardinal Albani over some four decades. The focus here, however, is on the 'pavilion at the bottom of the garden,' or the shed at the bottom of the garden, as common parlance has it. Albani's project was carried out in collaboration with others, notably the architect Carlo Marchionni and the German art historian and nascent archaeologist Johann Joachim Winckelmann. Closed to the public, access is occasionally granted by the owners, the Torlonia family, following application. Although superficial information about the villa is relatively abundant on the Internet, finding more in-depth, scholarly investigations and referenced literature is another matter.There is little in English; much is in Italian, but the most is in German, following perhaps the significant involvement of Winckelmann, who was Alessandro Albani's protégé, librarian and companion.

One of the main sources is Forschungen zurVilla Albani, edited by Herbert Beck and Peter C. Bol (1982), a volume with contributions by various scholars, 


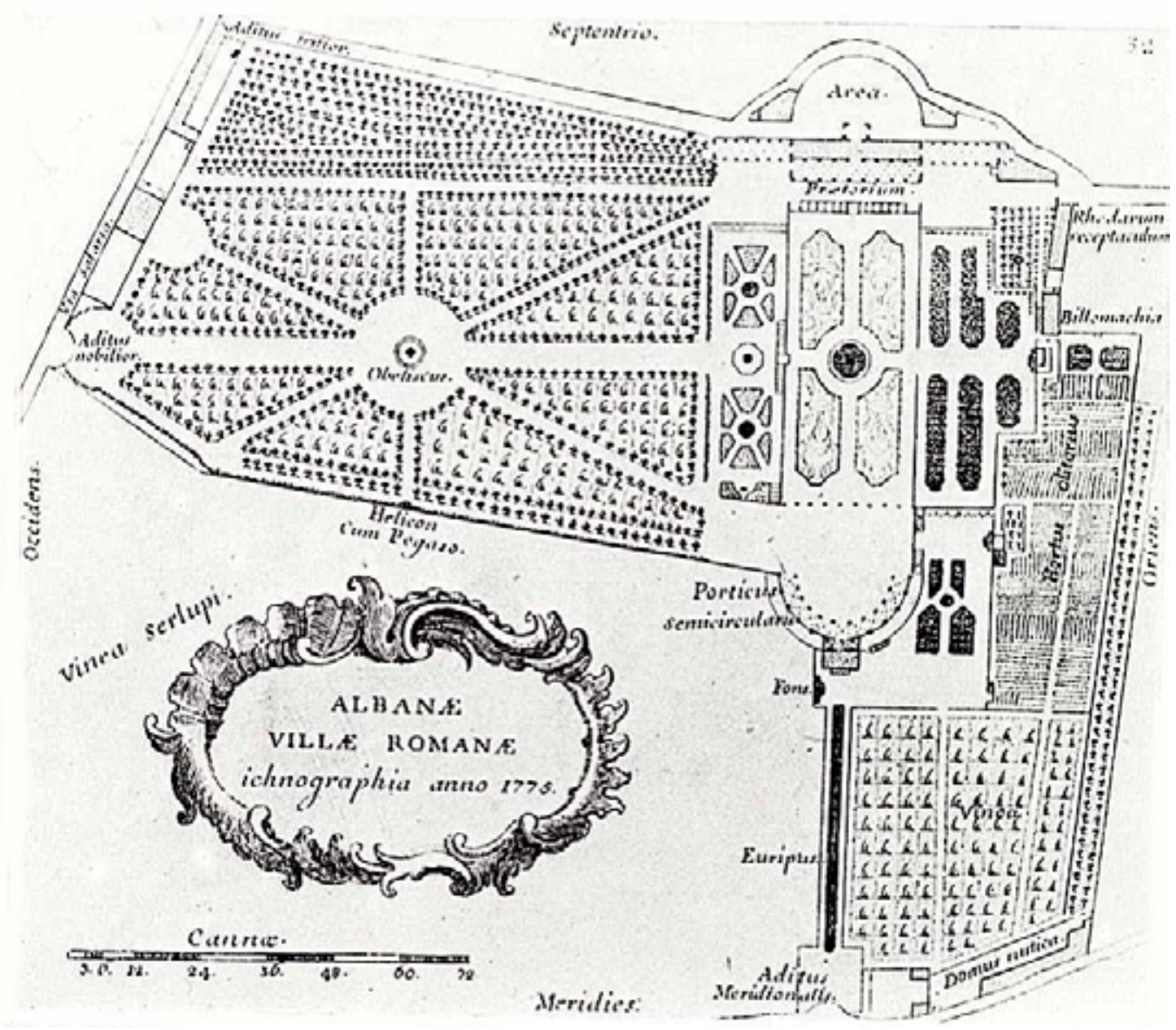

Figure 2. I: Plan of Villa Albani, Domenico Magnan, 1775.

among them, Steffi Röttgen who has examined archival material of Albani's transactions and Winckelmann's copious multilingual correspondence, crafting a detailed biography of the villa. The texts raise a number of questions, however, and introduce ambiguities that warrant further examination regarding the project. Also curtailing research and a more comprehensive study of the villa is the fact that much documentation, including several drawings and some letters of relevance are scattered over various European and American libraries, public and private archives and museums.

Biographies are helpful, but only up to a point. Carl Justi's biography of Winckelmann, Winckelmann und seine Zeitgenossen ([1867] 2002), concentrates on the man's life and times (17|7-68) in his native Prussia and his thirteen-year sojourn in Rome where he enjoyed the successive patronage of three significant cardinals: cardinal Archinto, who initially encouraged Winckelmann's conversion to Catholicism and his move to Rome; cardinal Passionei, who was at one time head librarian at the Vatican; and cardinal Albani, who of the three had the strongest influence on Winckelmann's life and was himself influenced by him. Justi's biography is based on excerpts from Winckelmann's correspondence and other sources, which are unfortunately not cited. Still, his is the main text and key to understanding the subject's complex character. A later English biography, Winckelmann, by Wolfgang Leppmann (1970), is heavily reliant on Justi. Neither biography contributes to an understanding of Winckelmann's influence specifically relating to the Caffeaus.

Dionigi Strocchi's Latin biography of Albani (De Vita A. Albani Cardinalis, 1790) is referenced by later authors, such as Röttgen in her chapter, 'Alessandro Albani' (Beck and Bol, 1987), and Leslie Lewis in her book, Connoisseurs and Secret Agents in Eighteenth Century Rome (196I), which deals exclusively with Albani and his friend Baron Philipp von Stosch. Justi's biography of Winckelmann contains a chapter devoted to Albani's life. Again, however, none of these texts shed much light on the Caffeaus.

Joachim Gaus's biography Carlo Marchionni, Ein Beitrag zur römischen Architektur des Settecento (1967) mentions the architect's personal relationship to Albani; but gives frustratingly little detail of what this may have been. However, that relationship was significant enough for Albani to have been godfather to Marchionni's son. Gaus states that Marchionni was directly involved with the design of the villa and its pavilion, yet while the book contains some drawings to this effect, there are no details or descriptions of the work, its progression 
or the ornamentation and furnishing. Some of this information can be found in Winckelmann's letters to friends and acquaintances, relevant passages of which have been quoted by authors in other texts. But in his copious writing, Winckelmann never mentions Marchionni, and so apportioning authorship of the villa remains uncertain.

The garden pavilion (its structure and ornamentation, its significance and use) might be seen as a separate study within the scholarship associated with the villa.Yet, because the pavilion is like an ornamental extension of the villa, it still needs to be examined in regard to the larger architectural landscape. What follows here is a presentation of the pavilion in its larger context in order to help bring to life, for an English-speaking audience, cardinal Alessandro Albani's tremendous architectural and intellectual undertaking. It demonstrates how the often dismissively referred to 'shed at the bottom of the garden' can assume a form that embodies erudition and narrative, producing a structure rooted in classical precedence and reflecting a world view, to which Winckelmann's highest praise, "edel Einfallt und stille Größe" [noble simplicity and quiet grandeur], might well apply.

To the urban explorer, Villa Albani first appears as an enclosure, a tall perimeter wall upon which political and cultural posters are stuck, graffiti is scrawled and plaster spalls. The trunk of a long-dead tree is embedded in it, signalling a moribund villa in the present day. Following the wall to the north, around the corner into via Ada, one will see that it gives way to the back of the western, side portico of the main building - the Casino, as it is called - its yellow ochre and white plasterwork contrasting sharply with the grimy grey of the wall. Here a tall metal gate is today's private entrance to the villa, a security camera mounted discretely on one of the two columns that hold the gate. Although the Casino and one of the service buildings are uninhabited, there are signs of upkeep and life in another.Above the spikes of the gate can be seen the projection of the porte-cochère and the rooms above it at the back of the Casino. .This architectural element with its north-facing balcony marks the beginning of an axis which passes through the Grand Gallery on the Piano Nobile, across the sunken parterre de broderie, and on to the exedra of the pavilion to the south.

The Caffeaus, as the pavilion is called, can be viewed by either circumnavigating the entire block or by retracing one's steps down via Salaria. On the southern corner where the road is intersected by a small cul-desac side street, via di Villa Albani, the wall curves inward,

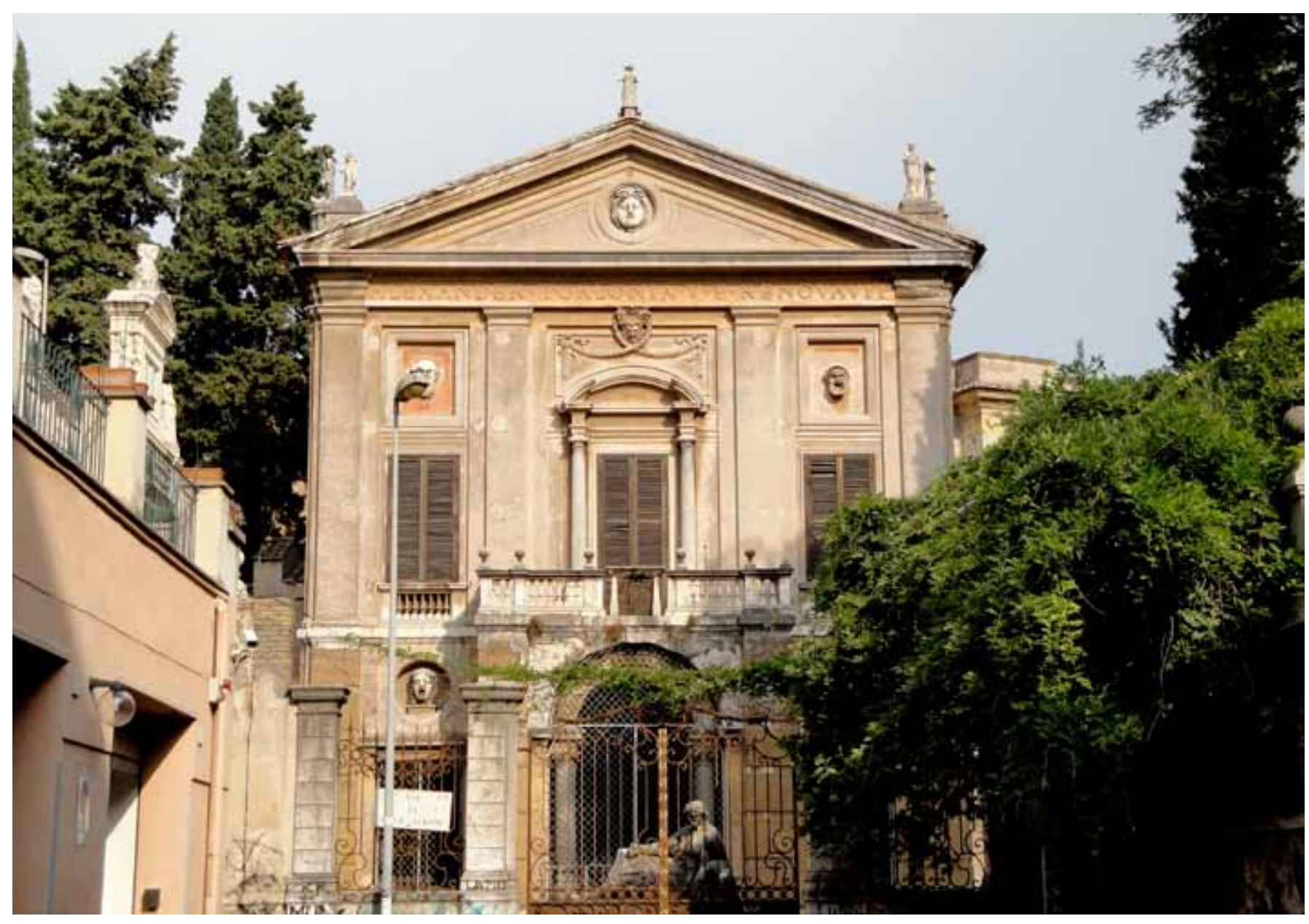

Figure 2.2: The lodge of the Caffeaus, Villa Albani, 2009. () Jane Lomholt 
becomes higher and is corniced. Separated into bays by shallow pilasters, this concave arc is open at the centre with two fine, square columns of travertine marking the garden entrance to the estate. There are large urns with dried agave spears atop the pilasters, but the tall, travertine pillars, ancient and elegant, are decorated with carved, weathered herms and surmounted by sphinxes. Through a tall, rusting iron grille, one glimpses the garden beyond, laid out with clipped hedges and an avenue of trees. A central verge of sparse brown grass is punctuated at intervals with the nude vestiges of rose bushes. This east-west axis focuses on a tall obelisk crowned by the Albani-Chigi emblem; it stands in a circular piazza surrounded by ancient statues in various states of decay, some with limbs or parts that are wired to their bodies or missing altogether. In the far distance, the axis terminates at the so-called Jupiter Aedicule. On my visit, I was surprised to hear bird song and the pleasant trickling of unseen fountains from within the walls.

Around the corner, at the end of via di Villa Albani, the terrain drops sharply, and steps lead down to another street, which finally allows the pavilion to be seen, squarely, from mid-level. It is a two-storey, pedimented lodge with a loggia at ground level situated in a courtyard below this street. The building sits incongruously against the hardly perceptible semicircular portico above at the level of the parterre. Despite its air of dereliction, the lodge is imposing, a classical building lost in time and space. Of three bays expressed by four pilasters which are heavily rusticated at the lower level, the central bay is pulled forward slightly, an architectural nod to the porte-cochère on the north side of the casino.

At ground level, this protrusion is expressed by a tall, Serlian arch with Tuscan columns, leading into a loggia (the Porticus Romae) and terminating above in a stone balcony, where an arched doorway, decorated with swags and a mischievous mask, leads to the interior space of the upper ground level. Strong metal-wire screens cover the loggia openings at lower level, while the corresponding window and door openings above are closed with fragile wooden slatted shutters. Framed, grimacing masks are embedded in the render of the façade above the openings as well as in the centre of the tympanum of the pediment. Engraved on the architrave of the building are the words: ALEXANDER TORLONIA V P [vir princeps] RENOVAVIT.

In former times, the courtyard served as the southern entrance to the villa, but now it is closed

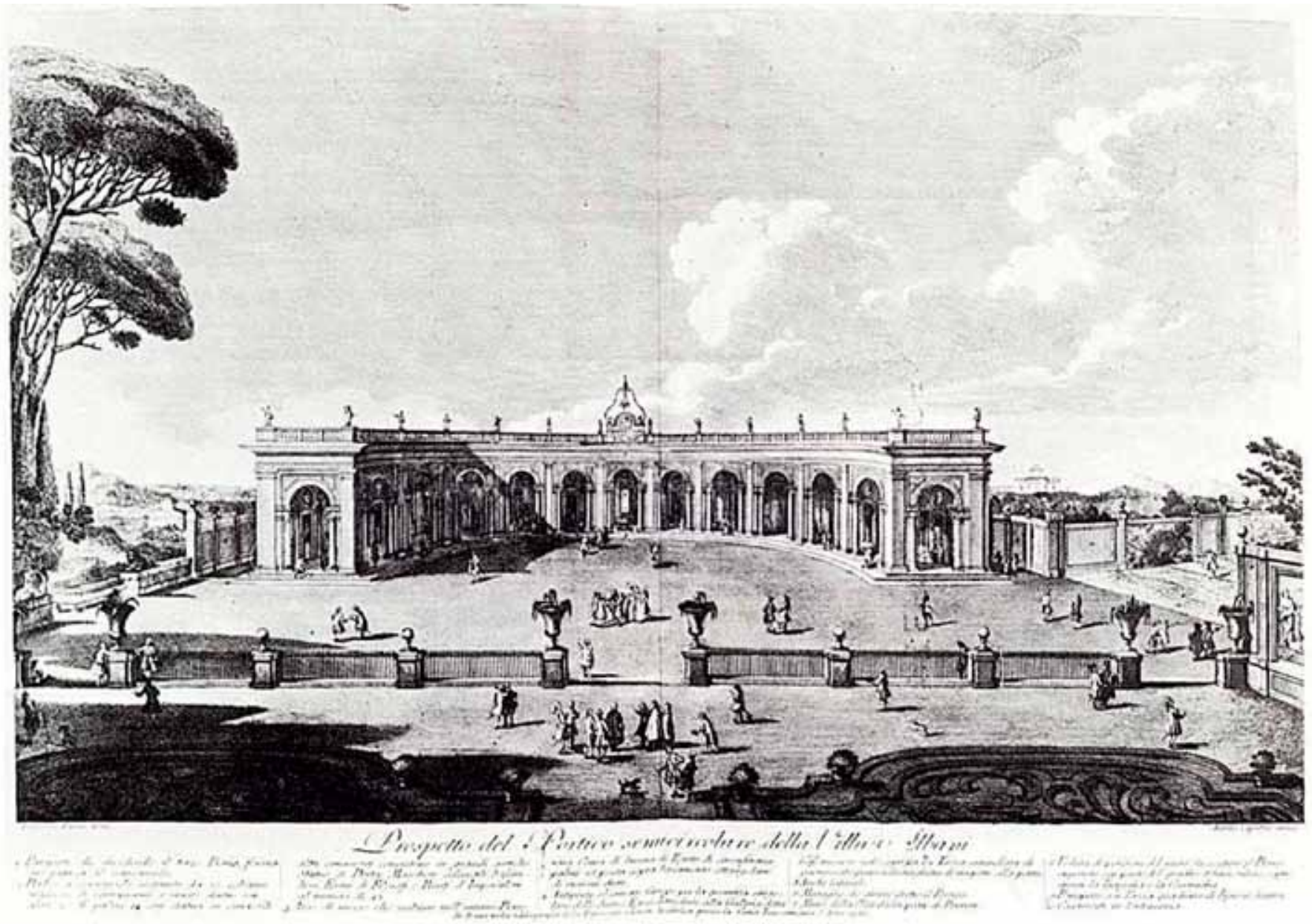

Figure 2.3: Semi-circular portico of Caffeaus by Francesco Panini (after 1780). 
off by rusty railings and a firmly secured gate. A large, elaborately decorated alcove in the courtyard's western wall is filled by an encrusted sculptural monument and fountain, the Fons Larvae, the Mask Fountain. ${ }^{2}$ The frame of the alcove consists of two bas-reliefs of life-sized Roman soldiers placed above framed masks of equal width. Standing just proud of the wall on either side of the fountain are two lonic columns. In the centre of the courtyard, a commanding granite colossus depicting

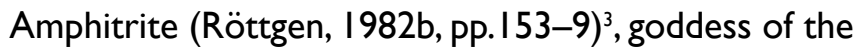
sea, reposes against what appears to be a compliant calf. To both sides, in deep niches of the retaining walls, are masks of longhaired, bearded Tritons. Now remote from her domain, Amphitrite looks out at a mundane urban drive that gives access to a series of lock-up garages, which in more recent times has replaced the magnificent cascades (Fons Euripi) that once flowed from beneath her. ${ }^{4}$

From within the gardens above, the pavilion assumes its relatively familiar image, a semicircular portico, recognised from photographs, prints and plan drawings. ${ }^{5}$ Tuscan columns are arranged with pilasters in the Serlian manner, the taller supported by two smaller, in the outer arc of the portico, dividing it into eleven bays. The acroterion at the apex of the pitched roof of the lodge is visible above the balustrade of the lower semicircular roof. The width of the exedra equals the width of the Casino; the pattern of the columns and pilasters of the exedra corresponds to that of the nine-bay lonic columns and pilasters of the Casino, though there the height is much greater, further emphasised by its elevated position. The arms of the

2 In the alcove of the fountain, a disembodied head (mask) appears above the heavy growth of ivy and sculptural encrustations that fill most of the niche. See plates 119 and 124, as well as figures 224, 243 and 244 in Beck and Bol (1982).

3 In a letter dated 19 October 1765 to his friend Schlabendorf, Winckelmann enthusiastically writes: 'Der Herr Card. hat einen weiblichen völligerhaltenen und liegenden Colloßalischen Fluß von Tivoli mit 16 Büffel-Ochesen holen lassen, welcher über die Mündung der Cascata gesetz ist...' (Röttgen, I 982, p. I 58). However, Carl Justi (2002, p. 28) states that the statue of Amphitrite was brought from Tivoli by six oxen (' ... ward die Amphitrite durch sechs Büffel herüber gefahren.')

4 Amphitrite is anchored, so to speak, by a reclining Neptune (analogous to Poseidon, Amphitrite's mate) in a niche at the north end of the parterre below the Casino terrace. The Tritons were the offspring of Amphitrite and Poseidon.

5 A number of comprehensive plan drawings of the villa by Domenico Magnan, I775/76, are published in Beck and Bol (1982). A later plan drawing by Percier and Fontaine ([1809 [2003], p. 50, plate 2) does not show the gardens west of the parterre, but includes a 'key' for locating various structures. exedra reach out in welcome, and a few small, round metal tables and chairs invite the visitor to linger. In the deep shadows of the vaulted portico, classical statues of deities and other mythological characters slowly achieve definition and animate the scene.

A retainer opened for me the double wooden door, which leads into a small, oval-shaped space, stark and funerary. The room beyond, the Canopeum, is dark and musty, and the kindly man opened the floor-length wooden shutters at either side, letting in light and a cooling breeze. As if by magic, the vaulted room appears to double in extent. Two steps lead up to another set of doors and into yet another room. This is the room of the balcony, the Diaeta, which Justi states is the actual 'Caféhaus'. ${ }^{6}$ Sadly, it is now used as a storeroom. A large table in the centre is piled with apparently insignificant objects, and discarded pieces of furniture are stashed against the walls. There is no trace of Clérisseau's mooted wall paintings of classical landscapes in either room (McCormick, 1990, pp. I00$10 \mathrm{I})$, little trace of painted walls at all; the plaster is flaking. The shutters are again closed, the key is turned in its lock.

Giambattista Nolli's Pianta di Roma of 1748 provides a sense of how the pavilion was originally situated. It shows a large parcel of land on via Salaria designated as belonging to His Eminence Cardinal Alessandro Albani.This land already had structures on it: a group of buildings along via Salaria, a roofed portico to the north, and directly to the south, at the bottom of a garden, a semi-circular wall.Albani bought the land in 1747, so Röttgen surmises that it was already laid out as a garden and that these structures were pre-existing (Röttgen, 1982a, p.63).An early design by Marchionni extended the buildings along via Salaria into a formal composition, but the design was not executed. In later drawings Marchionni refers to them as the 'old casino' and there are vague indications of them on some of his sketches. The design of the villa that followed responds strongly to the two porticos. William Collier suggests convincingly that the north portico was actually incorporated into the new Casino, which was then built around, behind and above it (p.340). The given levels of the land have been important, the design making interesting use of them, possibly even contravening what nature has provided. Innumerable drawings testify to Marchionni's involvement in the project, but it is generally acknowledged that he worked closely to Albani's own design ideas, with Winckelmann professing

6 Justi (2002, p.293) does not mention the Diaeta, but states that the "Caféhaus" was appended behind the 'Canopus' ('... dem "Canopus”, dahinter wurde um dieselbe Zeit das Caféhaus [sic] angehängt'). 


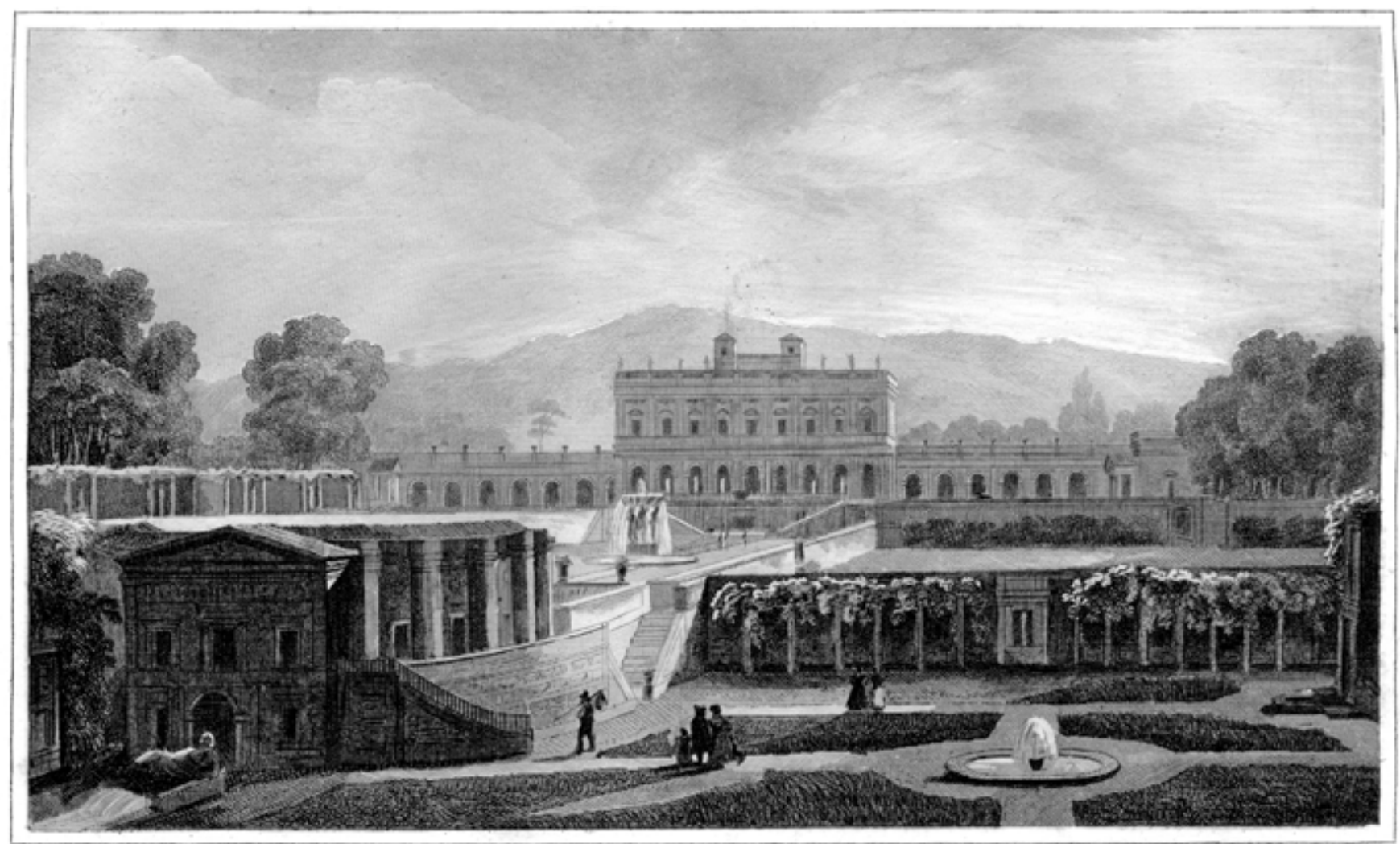

Figure 2.4: Southeast view of Villa Albani with Caffeaus, early nineteenth century (Bouchet and Aubert) (C) Jane Lomholt

to a friend that Albani himself was the sole architect of the villa (Justi, 2002, p.292). ${ }^{7}$

A new garden layout and general landscaping is credited to Giambattista Nolli (Lomholt, 2012, p.50), the steeply sloping land to the south levelled to enable building the semicircular portico, which was finished in 1753. The appended, south-facing building, the lodge, was of a later date, most probably as late as 1764, when Winckelmann wrote to a friend that the cardinal has 'hung' a large building (the Caffeaus) off the semicircular portico. He added that this new room, like the gallery, is of marble. Presumably, he is referring to the Grand Gallery of the Casino, which was completed a year or so before this later addition (Röttgen, 1982a, p. 104). ${ }^{8}$ Röttgen also refers to - but does not identify - a contemporary text on Roman art by Giovanni Gaetano Bottari, published before the addition was built; this mentions a room behind the semi-circular

7 Winckelmann writes that Albani is the 'einzigen Baumeister der Villa'. Gaus puts it another way, saying that no one would doubt Marchioni being ascribed as the architect of the Villa, but that it is difficult to determine what his specific contributions were, adding that he spent his days with the construction work but increasingly concerned himself with details (Gaus, 1967, pp.28-9).

8 Röttgen refers to a letter by Winckelmann, dated 7.12.1764, in which he writes, 'Der Cardinal hat in seiner Villa hinter dem runden Portico ein groß Gebäude angehänget, wo er einen Saal lassen, welcher, sowie die Galerie von Marmor ist....' portico on the north-south axis, which was furnished with seven Egyptian statues. ' It is probable that this earlier room is a gallery built in conjunction with the semi-circular portico, finished in 1753, and that this is the same as the one there today.

When Pope Benedict XIV visited Villa Albani in the autumn of I753, 'work on the villa' was well advanced (Röttgen, 1982a, p.65). 'Villa' in the Italian context, of course, refers to an estate, not a single building, so 'work on the Villa' is ambiguous and could refer to any part of the whole or the whole itself. As work on the Casino first started around 1755, presumably Röttgen's reference is to the north and south porticoes, the gardens and the deployment of statuary. The pope's attendant Abbot Bracci wrote to a friend that this was 'a villa gallantly designed and decorated with many thoughtful antique monuments including statues, busts of eminent men and philosophers, colossal heads, basreliefs and such', which were the envy of more famous villas in Rome (Röttgen, 1982a, p.65, n.I I). In other words, the exact state of the pavilion is uncertain at the time of the pope's visit. However, it is certain that the portico itself was finished in 175I, and it is probable that the additional room and the furnishings and ornaments were in place by the time of the visit.

Commercial coffee houses were common in eighteenth-century Rome. However, like their English

9 Röttgen (1982a, p. 104) mentions an untitled publication from 1763. 
counterparts upon which they were modelled, they had little in common with the private, intimate and elegant garden pavilions of the great houses where coffee, tea and chocolate could be imbibed at leisure in the afternoons; or to where one could simply retreat from the formalities of duty and responsibility (Coulton, 20 I2, pp.43-65). In I73 I, for instance, Fabrizio II Colonna commissioned the architect Niccolò Michetti to reorganise the west wing and façade of his family's palazzo on the Piazza dei Santi Apostoli in Rome, adding a pavilion there. Michetti had just returned from five years in Russia as Court Architect to Peter I, which no doubt gave him valuable experience and contributed to his 'highly original' design. ${ }^{10}$ Michetti's addition is a one-storey square tower placed on the roof of the south-western corner of the expansive palazzo. Initially referred to as the padiglione, the descriptor of 'Coffee House' was applied to it later. Integral to the palazzo, the Coffee House is expressed externally through its height and façade treatment. From on high, the western façade of this light and airy room addresses the city (with a view down the street to the Palazzo Muti, the home of the Stuart Pretender), while its opposing façade addresses the inner courtyard garden and in the near distance to the east, the Palazzo Quirinale of the popes. A roof garden extends to the north.

Stoschek describes the coffee house of the Palazzo Colonna as a one-storey pavilion which sits on top of a two-storey corner building, forming a large, well-lit room. There are tall windows on all four sides, the three to the west arranged in the Serlian manner (p.98).Although the interior of this elegant Roman baroque reception room has a square plan, the corners are cut by arches and inward-curving arcs supported by marble columns, reshaping the appearance of the room so that it was octagonal. The ceiling arcs are hollowed out, admitting light from lunettes above neighbouring windows, revealing scallop shells within the oval frames. The room is richly decorated. The walls are covered with marble panels and gilded stucco, and there are antique statues and bas-reliefs. Above some doors and windows are stucco tondi, and finely painted pendentives can be seen throughout. The ceiling is dominated by a large gilt-framed fresco by Francesco Mancini entitled Storie di Amore e Psiche, showing Psyche and Cupid after their innumerable trials, making their way to Mount Olympus, immortality and marital bliss. Against a heavenly background peopled by gods and cherubs, Psyche is carried aloft by Hermes while Cupid at her feet carries Hermes' staff. Great attention was given to the details of the room, as can clearly

10 Transcript of English translation given in Micalizzi (2003, p.18). be seen, and although various artists are mentioned in connection with its ornamentation, there is no information about how it was used.

Ten years later, in June I74I, the new pope, Benedict XIV, instructed the architect Ferdinando Fuga to design a pavilion in the garden of the Quirinale Palace.The location of the pope's pavilion is to the north of the formal garden where an earlier structure appears to have been situated. Similar to the Caffeaus of Villa Albani, that of the Quirinale (built ten years earlier) overhangs a sheer drop, but in contrast to it, an insignificant door leads to a basement or cellar. The north elevation (the back) bears no semblance to the 'back' of the Albani Caffeaus, which has its own rich story. Fuga has designed a surprisingly restrained three-bay, single storey pavilion, simply articulated with shallow Tuscan pilasters and profiled cornicing. The two side bays are extruded from the centre by as much as the width of the bay, yielding a double square floor plan, and together, the two bays provide a frame for a central, elevated terrace. The front and centre side elevations of the bays have long, pedimented windows with seating consoles below. The receding centre bay has three tall French doors, separated by shallow pilasters, with semicircular fanlights above. These doors open into a vaulted entrance hall, referred to as a portico, a closed portico. On the opposite (back) side of the portico are three corresponding doors, the central one opening onto a balcony, originally providing views out over the city, now limited by the encroachment of neighbouring buildings.

The two inner chambers are relatively small but with high, ornate ceilings and rounded corners. Decorated in pale pastel colours, the walls are divided up by gilded stucco frames within which appear paintings of religious themes by famous artists of the time, among them the sought-after portrait painter Pompeo Batoni and Giovanni Paolo Panini (whose veduta of Santa Maria Maggiore clearly shows Fuga's exuberant baroque work). The rooms were furnished with relatively casual furniture, comfortable chairs, sofas and small tables, as befitting a garden pavilion. The chamber to the right differs from that to the left in that it has a fireplace, complete with hearth brush and bellows. This may be seen as an attempt by the pope to emulate the fashionable English 'coffee house', the term he himself used, reflecting an image of 'Englishness' as translated to Rome (Stoschek, 1999, p. I45). Stoschek comments that the fireplace utensils were no doubt sent from England, but the furniture was 'in the French taste'.

Because the pavilion was to serve as a retreat for the pope, away from the formalities required by his official status, the Caffeaus was a place where etiquette was 
abandoned. Although he held private audiences here, it was specifically intended for his own pleasure and ease. $\mathrm{He}$ enjoyed walking in the gardens, breathing the fresh air, and then retiring to the pavilion alone or with his ambassadors or closest aids. Coffee was undoubtedly served in there, Stoschek says, brought from the kitchens of the palace, but the pope himself, by his own admission, preferred chocolate (p.I48).

The papal pavilion could well have been lost from public memory (it is not open to the public) had it not been for one significant political event - the reception there of Charles VII of Naples (Charles V of Sicily) in November 1744 and Panini's record of it in his controversial painting, Charles III of Naples Visiting Pope Benedict XIV in the Quirinal Caffeaus (1746). Dressed in gold coloured velvet with diamond buttons, Charles rode through the Porta Pia into the city. Led by the pope's own Swiss Guard and accompanied by 50 officers in dress uniform and 480 cavalry soldiers, he proceeded to the Quirinal Palace. He was received by the pope in private in the right-hand chamber of the Caffeaus, the more informal room. The audience lasted one hour, after which the King declined refreshment and left." In his painting, Panini takes liberties. He shows the pope seated in the left-hand chamber, awaiting the King, who is shown with entourage on the terrace at the centre of the painting. As Joseph Rykwert noted about this painting, he has also significantly altered the architecture of the pavilion, perhaps in critique of Fuga's design (pp.34I-2). Panini emphasises scale, proportion and architectural detail, which Fuga had intentionally judged inappropriate for this type of building. It is curious that Panini altered the room in which the audience took place. The meeting between the two rulers was politically sensitive. The choice of the room to the right, with its tokens of domesticity, may have been specifically chosen in an attempt to maintain etiquette between the two rulers but at the same time, to disassociate Pope Benedict from political implication in the King's controversy with Austria. It was an official visit in the guise of informality.

As the drinking of coffee (tea and chocolate) in a garden pavilion became fashionable, many existing pavilions, including the roof pavilion of the Palazzo Colonna, as well as other previously existing garden pavilions, became referred to as the 'coffee house' or 'caffeaus'. The caffeaus located its owner in a social context, signalling an awareness of style and fashion,

II For details of the visit, its complicated etiquette and interpretations of the meeting place, the Caffeaus, see Stoschek (1999, pp. 163-72). Stoschek also discusses Panini's painting of the event and his re-design of the building in the painting. wealth and education. It provided an environment for the display of fine art, as well as specially crafted porcelain, and presented a refined but casual backdrop to the art of conversation. No doubt, it also served as a place where learned discourse took place, where art itself could be discussed while referring to examples that were readily at hand. The word 'caffeaus' was a neologism, a word made up to refer to pavilions that were for the most part on private grounds. It was an imprecise, generic term, used at this time in these contexts; it was not a building type.

In discussing the etymology of the term, Stoschek refers to a 1741 diary entry by the Abbé Ludovico Francesco Valesio, which she cites in her introduction (p.2), connecting this information with her examination of the terms used to refer to a villa garden pavilion (Stoschek, 1999, p. I4I). Although 'caffeaus' was known and used, Stoschek suggests that Valesio's entry is the first time the term appeared in print, but adds that it also appeared on a contemporary plumber's invoice. 'Caffeaus' (without the accent) was applied to Pope Benedict's pavilion at the laying of the foundation stone. The term Coffee House was applied to the pavilion at the Palazzo Colonna after this time. One finds minute variations in spelling that tend to reflect the authors themselves, their nationalities and the bases of their research. Thus the variants of the following terms may be equated: Cafféaus (with lower or upper case, with accent or not) and coffee house (with lower or upper case, with or without hyphen, or as one word). Justi refers to the Caféhaus. Thomas McCormick uses the compound form, coffeehouse, in his own language. ${ }^{12}$ Stoschek, writing in German, uses Caffeaus, without accent and with upper case, as one does in German recognition of all nouns, proper or not. Beck and Bol's volume uses Kaffeehaus, the compound German word, made up of the words for "coffee" and "house". Cafféaus is used in some Italian texts, as is caffraus. Charles Percier and Pierre François Léonard Fontaine merely use the French word, café, as we know it today, which simply refers to the drink but bears none of the history or more exotic connotations of the made-up terms.

Percier and Fontaine describe the setting of the Villa Albani Caffeaus, following their visit there at the end of the eighteenth century, saying, 'The café is preceded by a vestibule and a "circular gallery", where the walls are decorated with statues, columns, vases and antique bas-reliefs. This building which is situated in the most

12 McCormick (1990, p. 100), in connection with his brief but detailed discussion of the possible commission given to Clérisseau to decorate an interior room in the Albani pavilion. 
beautiful position within the villa, [...] dominates a long cascade formed by discharging the waters of the parterre' (p.48). Their description manages to convey a strong appreciation for not only the building and the art, which was of acknowledged high acclaim, but also the situation of the pavilion.

Another plan by Domenico Magnan, which illustrates the Caffeaus of the Villa Albani, avoids the word altogether, using only Latin terms. He has entitled the drawing ALBANAE VILLAE ROMANAE PORTICUS SEMICIRCULARIS ICHNOGRAPHIA. The drawing shows the semicircular form of the portico with an outer (unroofed) concentric corridor on either side, the left leading to the wooden side-shutters of the Canopeum and a narrow staircase down to the Porticus Romae; and the right, to the opposite side shutters and a small, internal circular staircase, presumably giving access to the roof. While the Canopeum is marked as such, the room referred to as the coffee house proper is labelled Diaeta, implying diet or dietary regime in Latin. The oval entrance space between the portico and the Canopeum is not named but clearly defined on the drawing. In the mid-1800s, it was believed that the Canopeum had a connection to canopic jars, but there is no evidence of this ever having been the case. However, it does suggest that the Canopeum was considered to have a funerary aura. Justi states simply that 'Canopus [sic]' is the same as the 'Egyptian cabinet' (p.293).

The Canopus at Hadrian's Villa is a long rectangular body of water, richly decorated with statuary around its edges and with the semi-circular Serapium grotto behind it. The construction of the Canopus most probably dates to sometime after I30AD, the year Hadrian's young lover, Antinous, drowned in the Nile; it is possibly Hadrian's private architectural response to his deep public sorrow. One can only guess at what might have happened on the Nile, but one possibility is that Antinous 'sacrificed his life for that of the Emperor's'. This assertion by Carcopino is not singular, and he underpins his claim by associating Antinous' death and apotheosis with the cult belief in salvation (Pp. I5I-2). John Ward-Perkins writes that the Canopus at Hadrian's Villa, 'with its formal lake and Egyptianizing sculpture ... was a suggestive evocation, not a direct copy, of the famous sanctuary [of Serapis] near Alexandria after which it was named' (pp. 14, 109). The Graeco-Egyptian god, Serapis, was associated with resurrection and, by inference, with death. At certain times, he was conflated with Osiris - as was Antinous. A statue of 'Antinous as Osiris' was once located in the 'Vorraum der Galleria del Canopo' at Villa Albani, but it is now in the Munich Glyptothek (Allroggen-Bedel, 1982b, p.367).
It is likely that the Canopeum and its setting at Villa Albani may also be a 'suggestive evocation', in the words of Ward-Perkins, of the Canopus at Hadrian's Villa. No doubt cardinal Albani felt a certain affinity with Hadrian, whose grounds he had excavated over decades and whose treasures he had to some extent liberated. He was referred to by some as the 'Hadrian of his century' (Howard, 1992, p.27). Although there is no hint of Albani having male lovers, the figure of Antinous in various guises received much praise by art critics, including Winckelmann, and there were numerous depictions of Antinous at Villa Albani. In the Grand Gallery of the Casino, on axis with the Caffeaus, embedded in the wall facing the semicircular portico, is a large, full-figure bas-relief, Youth with Horse. At the bottom of the relief the name 'Antinous' has been added. The young man is nude, his riding cloak over his left arm, his right hand holding the bridle of a horse. This work has been restored (Albani was also known as 'restorer in chief'), as were many of Albani's sculptures, and is of uncertain provenance. Possibly the head of Antinous was chosen to replace a missing one. Another Antinous relief is the better known portraitrelief, slightly smaller than the former, embedded in the chimneybreast of the neighbouring room, which was designed for the portrait and named after it. It is credited with having been excavated at Hadrian's Villa in 1735 and acquired by the cardinal the following year, but its provenance has been called into question (Vout, 2007, pp.93-1 18). Whatever the truth of the matter is, this does not alter the eighteenth-century perception that it is a relief from Hadrian's time, found at his villa, and therefore it carries meaning accordingly.

The deployment of Antinous figures, as all pieces of art at the villa, were specific, and Winckelmann no doubt played an active part in these decisions. Agnes Allroggen-Bedel emphasises the Egyptian theme at the Caffeaus. She refers to the Diaeta (a term she only uses once) as the 'Galleria del Canopo', furthermore, she identifies Magnan's Canopeum as the 'Vorraum der 'Galleria del Canopo' (Allroggen-Bedel, 1982b, pp.367-8.), the anteroom of the Gallery. In other words, the nomenclature of the two spaces is not consistent. The book's 'Konkordanz' ['Index of Art Works and Their Location'] lists a number of Egyptian statues and busts as having been displayed in the anteroom, including a statue and several busts of Osiris, a statue of Isis, and a statue of Antinous as Osiris (see above). But AllroggenBedel points out that today much of the art throughout the villa is so differently deployed ('... so grundlegende anderes') or missing altogether, that it is hardly possible to approach the concept of the cardinal 
without reconstructing his original collection and its positioning. ${ }^{3}$

Elizabeth Schröter has examined the Villa Albani as 'Imagio Mundi' '4 and gives compelling insight into what may have been Albani's over-arching narrative, the tapestry upon which he and Winckelmann continually embroidered. She sees the ceiling fresco, Parnasus, by Anton Raphael Mengs, in the Grand Gallery of the Casino, as dominating the entire mythic-historiccosmological tableau; it is the fix-point of the project, with Apollo, depicted here surrounded by Mnemosyne and her daughters, as the 'helmsman' and the protector of Rome. In the oval salon, preceding the Grand Gallery, is a ceiling fresco by Antonio Bicchierari showing the central and dominating figure of Aurora (Vigilantia) pointing with her left hand to the dark edge of the oval where Night with her two children, Death and Sleep, can be seen. As Aurora, the main figure announces the arrival of Apollo the Sun, and as Vigilantia, she contemplates and anticipates night, sleep and death. The figure not only heralds what is to come, but foreshadows the theme that is portrayed in the Canopeum.

The ornamentation of the semicircular portico, the Canopeum and the Diaeta displayed Roman mythical personae and events, many elided with their Greek counterparts. Represented in fine sculpture, though often restored, the statues, reliefs and other works of art were placed in dialogue with one another and with their narrative correspondents in the Casino. The statues of ancient Greco-Romano deities, gods of the zodiac, who had served Rome or had won a place in Roman hearts, were assembled in the portico. Each arch was home to a major figure:Apollo as the cosmic ruler of Rome, at the centre, directly across from Mengs' Parnassus; Aeschlepius, Apollo's son, called 'the healer', who delivered Rome from the plague of $193 \mathrm{BC}$, stood to his right; next to him were Juno, then Diana, Pallas Athena (Minerva), and finally Mercury.To Apollo's left stood Jupiter, his father and the supreme ruler of all gods, then Venus (the mother of Aeneas, the mythical founder of Rome), the venerable Hercules, followed by two lesser figures, Thetis (the mother of Achilles, seen again on a sarcophagus relief in the Porticus Romae), and finally Bacchus, who was greatly

13 Allroggen-Bedel (1982a, p.303): 'Was der heutige Besucher antrifft, ist etwas so grundlegende anderes, daß erst nach einer Rekonstruktion des Ursprünglichen Bestandes und seiner Aufstellung das Konzept der Sammlung des Kardinals erkennbar wird.'

I4 Schröter (1982) suggests that the Jesuit scholar Contuccio Contucci, friend to both Albani and Winckelmann, most probably influenced the cosmic perspective of the narrative. admired by the Romans. Mars, the father of Romulus, was placed under the same arch as Apollo, but in a less prominent position. This pantheon gives Rome its preChristian religious foundations and aligns the planets of the cosmos.

These statues are saluted by those of Rome's mortal but deified forebears in the Grand Portico of the Casino at the other end of the garden. With entrance doors into the Casino at the centre of the portico, Augustus stands centrally to the left, adorned only with a wreath of oak leaves, and on either side of him are Tiberius and Lucius Verus, both in armour; to the right, in the middle, stands Trajan, with Hadrian and Septimus Severus on either side of him. Schröter suggests that these were meant to represent the virtues that lay at the foundation of an idealised Imperial Rome.

The pavilion at the bottom of the garden, the Caffeaus, carries meaning beyond its architectural value. Like the Casino, it is also a portrayal of the spirit of Rome, and inextricable from the broader narrative unfolding at Albani's villa. As the Casino 'at the front' was the entrance and the beginning of the narrative, so the pavilion 'at the back' was the exit, and the inevitable conclusion. The north-south axis formed by these two structures passes through the Oval Salon with the Vigilantia fresco and its only statue, a seated figure of Apollo. The entrance to this room leaves no doubt about the theme of the narrative; above the door is the inscription, ALEXANDER ALBANUS CARDINAL ROMANO ANIMO INSTRUXIT A.D. I 757. The Grand Gallery follows, with the Parnassus and the 'Antinous' relief. Across the garden, beyond a central fountain, through the semicircular portico with Apollo, is the Canopeum and the Egyptian sculptures, where Vigilantia resonates (in her contemplation of death). At the lower level the axis is supported by the Porticus Romae. In Albani's time, a seated Dea Roma reigned in the loggia, attended by Claudius and Augustus at her sides. The axis leads to the courtyard with its forbidding masks and the stony silence of Amphitrite. In former times the axis would have disappeared in the flow of the aptly named Euripus, that body of water whose strong currents and tidal waves were unpredictable and sometimes violent, a reminder of the Nile. The mythical references and the undertones of uncertainty, overseen by the blind eyes of the masks, lend a meditative and cautionary air to the courtyard. One is reminded of humankind's mortality; but the endurance of Roma eterna is still in the balance, perhaps due to the intercession of Antinous.

Winckelmann was murdered in Trieste in 1768, and cardinal Albani died ten years later, an old man, nearly blind. Having no interest or understanding of the 
villa project, or perhaps simply due to financial need, Albani's heirs sold off treasures piecemeal immediately after his death. A month later, 56 pieces, some of them priceless, were bought by Giovanni Battista Visconti, who succeeded Winckelmann as Director of Antiquities at the Vatican. Succeeding Winckelmann as Albani's librarian, the Jesuit scholar Stefano Antonio Morcelli, recorded in 1785 an inventory of 677 pieces of antique artwork. At the end of the century, Napoleon Bonaparte's troops plundered the villa, possibly in retaliation to the Albani family's resistance to French occupation and their support for Pope Pius VI. Five hundred and eighteen pieces of antique artwork were dismantled, crated and prepared for shipment to Paris, where many can be found today. Some found their way to Munich. Due to prohibitive shipping costs, relatively few works have been repatriated. Upon his purchase of the villa in 1866, Prince Alessandro Torlonia carried out extensive repairs to the Casino, Caffeaus and gardens but, sadly, it has remained closed to the public since then.

The villa, once a magnet drawing in the famous, the rich, the learned, the talented, now stands spiritually mutilated and physically crumbling, a memento mori to all and to Rome. Alessandro Albani devoted his long life to the study and collection of ancient art and invoked all that he knew and that he had, here, in honour of Rome. This once dashing and dapper young man served in various capacities as valued attaché to the Vatican, both at home and abroad; as an older man he was sought by the many seeking to benefit from his acquaintance. Through his beneficence and his grand architectural project, Albani placed himself (and the Albani name) firmly in Roman soil, in the Roman spirit, as Hadrian had done, and before him, Pliny, Cicero, and many others. It validated his position for posterity, in the spirit of Rome, Romano Animo, as he had intended.

\section{Bibliography}

I Allroggen-Bedel,A. (1982a) 'Die Antikkensammlung in der Villa Albani zur Zeit Winckelmann' in Beck and Bol (eds) Forschungen zurVilla Albani. Antike Kunst und die Epoche der Aufklärung, Berlin, Gebr. Mann Verlag p.303.

2 Allroggen-Bedel,A. (1982b) 'Konkordanz' in Beck and Bol (eds) Forschungen zur Villa Albani.Antike Kunst und die Epoche der Aufklärung, Berlin, Gebr. Mann Verlag, p.367.

3 Beck, H. and Bol, P.C. (eds) (1982) Forschungen zur Villa Albani.Antike Kunst und die Epoche der Aufklärung, Berlin, Gebr. Mann Verlag.

4 Burney, C. ([1770] 1969) Music, Men, and Manners in France and Italy 1770 (transcribed, edited and introduced by $\mathrm{H}$. Edmund Poole), London, The Folio Society.

5 Carcopino, J. (199I) Daily Life in Ancient Rome, The People and the City at the Height of the Empire, London, Penguin.

6 Collier,W. (1987) 'The Villa of Cardinal Alessandro Albani, Hon. FSA', Antiquaries Journal, vol.67, part 2, p.340.

7 Coulton, R. (2012) 'The darling of the Temple-CoffeeHouse Club: Science, sociability and satire in early eighteenth-century London', Journal for EighteenthCentury Studies, vol.35, no. I, pp.43-65.

8 Gaus, J. (1967) Carlo Marchionni, Ein Beitrag zur römischen Architektur des Settecento, Köln, Böhlau Verlag.

9 Henry James, H. ([1873] 2007) Italian Hours, Fairfield, IA: I ${ }^{\text {st }}$ World Library.

10 Howard, S. (1992) 'Albani, Winckelmann, and Cavaceppi, The transition from amateur to professional antiquarianism', Journal of the History of Collections, vol.4, no.l, pp.27-38.

II Justi, C. (2002) Winckelmann und Seine Zeitgenossen, vol.2, facsimile print, Bristol,Thoemmes.

12 Leppmann,W. (1970) Winckelmann, London, Victor Gollancz.

I3 Lomholt, J. (20I2) 'Villa Albani, repository of multiple narratives' in P. Emmons, J. Hendricks and J. Lomholt (eds), The Cultural Role of Architecture, London, Routledge.

14 McCormick,T.J. (1990) Charles-Louis Clérisseau and the Genesis of Neo-Classicism, London, MIT Press.

I5 Micalizzi, P. (2003) 'Roma nel XVIII secolo', Atlante storico delle città italiane - Roma 3, Roma, Kappa. 
16 Percier, C. and Fontaine, P.F.L. ([I809] 2003) Choix des Plus Célèbres Maisons de Plaisance de Rome et de ses Environs. Mesurées et Dessinées, A.H. Borbein and M. Kunze (eds), Mainz am Rhein, Philipp von Zabern.

17 Röttgen, S. (1982a) 'Die Villa Albani und ihre Bauten' in H. Beck and P.C. Bol (eds), Forschungen zur Villa Albani. Antike Kunst und die Epoche der Aufklärung, Berlin, Gebr. Mann Verlag, p.63.

I8 Röttgen, S. (1982b) 'Die Zeugnisse Winckelmanns zur Entstehung and zum Leben in derVilla' in H. Beck and P.C. Bol (eds) Forschungen zurVilla Albani.Antike Kunst und die Epoche der Aufklärung, Berlin, Gebr. Mann Verlag, Pp. I53-9.
19 Rykwert, J. (1982) 'Ephemeral splendours,' The First Moderns, Cambridge, MA, MIT Press.

20 Schröter, E. (1982) 'Die Villa Albani als Imagio Mundi' in Beck and Bol (eds), Forschungen zurVilla Albani. Antike Kunst und die Epoche der Aufklärung, Berlin: Gebr. Mann Verlag, pp. I85-299.

21 Stoschek, J.S. (1999) Das Caffeaus Papst Benedikts XIV. in den Gärten des Quirinal, Munich, Scaneg Verlag.

22 Vout, C. (2007) Power and Eroticism in Imperial Rome, Cambridge, University of Cambridge Press, pp.93-I I8.

23 Ward-Perkins, J.B. (2003) Roman Architecture I History of World Architecture, Milan, Electa Architecture. 